ACTA UNIVERSITATIS NICOLAI COPER NICI

DOI: http://dx.doi.org/10.12775/AUNC_ECON.2014.006

EKONOMIA XLV nr 1 (2014) 99-113

Pierwsza wersja złożona 29 listopada 2013

ISSN

Końcowa wersja zaakceptowana 15 czerwca 2014

2080-0339

Dariusz Piotrowski

\title{
ZASTOSOWANIE PODSTAWOWEJ ZASADY FINANSÓW ISLAMSKICH PLS CELEM OGRANICZENIA ZJAWISKA MORALNEGO HAZARDU NA RYNKU USEUG FINANSOWYCH
}

$\mathrm{Z}$ a rys treści. Moralny hazard wiąże się podejmowaniem nadmiernego ryzyka przez agenta $w$ ramach realizacji zadań powierzonych mu przez pryncypała. Pokusa nadużycia na rynku finansowym może wynikać z przeświadczenia, że ostateczne konsekwencje błędów popełnionych przez agentów poniosą klienci instytucji finansowych. To negatywne zjawisko można próbować redukować przez szersze zastosowanie formuły dzielenia zysków i strat. Zasada PLS jest jedną z cech charakterystycznych finansów islamskich.

$\mathrm{S} \nmid$ ow a k $1 \mathrm{u} \mathrm{c} \mathrm{z} \mathrm{ow} \mathrm{e:} \mathrm{moralny} \mathrm{hazard,} \mathrm{finanse} \mathrm{islamskie,} \mathrm{doradztwo} \mathrm{finansowe,} \mathrm{dzielenie}$ zysków i strat.

K l a s y i k a c j J E L: D820, Z120.

\section{WSTĘP}

W ekonomii klasycznej przyjęto założenia dotyczące racjonalności postępowania jednostek, dążenia do maksymalizowania użyteczności oraz powszechnego, darmowego dostępu do pełnych i rzetelnych informacji o stanie rynku. Założenia te upraszczały rzeczywistość i pozwalały na jej modelowanie. Problem w tym, że skomplikowane, zmatematyzowane modele ekonomiczne tworzą złudne przekonanie o panowaniu nad przebiegiem oraz poziomem ryzyka procesów gospodarczych. Nie sprawdzają się także

\footnotetext{
* Adres do korespondencji: Dariusz Piotrowski, Uniwersytet Mikołaja Kopernika, WNEiZ, ul. Gagarina 13A, 87-100 Toruń, e-mail: darius@econ.umk.pl.
}

(C) 2014 Uniwersytet Mikołaja Kopernika. All rights reserved. http://www.aunc.ekonomia.umk.pl 
w konfrontacji z rzeczywistością, czego dowiódł najdobitniej ostatni kryzys finansowy (Rudolf, 2012, s. 13-14). Problem ten dostrzegło wielu ekonomistów, w tym przedstawiciele nowej ekonomii instytucjonalnej. Wskazywano na fakt funkcjonowania jednostek w pewnym otoczeniu prawnym, organizacyjnym, moralnym, kulturowym, religijnym i wpływu tego otoczenia na decyzje podejmowane przez te jednostki (Włudyka, 2012, s. 48-50). Sformułowano poglądy dotyczące istnienia kosztów transakcyjnych oraz zjawiska asymetrii informacji (Williamson, 1998).

Moralny hazard jest przykładem efektu zewnętrznego mogącego zakłócić prawidłowe funkcjonowanie rynku. Objawia się przenoszeniem negatywnych skutków decyzji jednych podmiotów na inne. Występuje wówczas różnica w korzyściach i kosztach ponoszonych przez strony kontraktu. Moralny hazard, zwany także pokusą nadużycia, kojarzony jest zwykle z ubezpieczeniami. Zjawisko to można jednak zaobserwować również na rynku kapitałowym i w bankowości. Wiąże się z podejmowaniem przez agenta nadmiernego ryzyka, czemu towarzyszy przeniesienia ewentualnych strat, obciążenia kosztami błędnych decyzji finansowych pryncypała, którym najczęściej jest obsługiwany klient. Działaniami agenta kierować może chciwość, brak rozwagi lub przekonanie o byciu chronionym przed negatywnymi następstwami podjętych decyzji. Często w takich sytuacjach zysk przypisywany jednostce stoi w opozycji do strat ponoszonych przez grupę obsługiwanych klientów, lub szerzej, przez całe społeczeństwo. Dzieje się tak, gdy ostatecznie to państwo występuje w roli pryncypała instytucji finansowych.

Jednym ze sposobów redukcji zjawiska moralnego hazardu jest zastosowanie znanej z finansów islamskich formuły uczestnictwa w zyskach i stratach. Zasada ta obok zakazu pobierania nadwyżki, utożsamianej niesłusznie tylko z oprocentowaniem, stanowi filar teorii i praktyki finansów opartych na regułach szariatu. Celem pracy jest przedstawienie istoty koncepcji profit and loss sharing (PLS) oraz ukazanie wpływu jej zastosowania na redukcję zjawiska moralnego hazardu. W pracy zaprezentowane zostaną także uwarunkowania oraz potencjalne skutki implementacji omawianej zasady w procesie świadczenia usług finansowych dla klientów nieprofesjonalnych.

\section{NOWA EKONOMIA INSTYTUCJONALNA - WYBRANE TWIERDZENIA}

Przedstawiciele neoinstytucjonalizmu krytykowali neoklasyków za pomijanie w analizach procesów decyzyjnych wpływu czynników o charakterze pozaekonomicznym. Dopuszczali możliwość podejmowania decyzji, które nie byłyby optymalne z ekonomicznego punktu widzenia (Bartkowiak, 
2008, s. 135). Wierzyli, że podejście interdyscyplinarne pozwoli lepiej wyjaśnić i przewidzieć zachowania jednostek, które nie zawsze cechuje racjonalizm i automatyzm dostosowań. Stworzyli pojęcie instytucji, czyli ukształtowanych $\mathrm{w}$ drodze ewolucji i akceptowanych $\mathrm{w}$ danej społeczności wzorców zachowań, zwyczajów, postaw i sposobów działania (Stankiewicz, 2007, s. 223-224). Istnienie wartości takich jak prawo, kultura i religia zapewnia ład gospodarczy. Wzrost przewidywalności zachowań i zaufania między stronami kontraktów pozytywnie wpływa na skalę realizowanych transakcji oraz obniżenie kosztów z nimi związanych.

Neoinstytucjonaliści zauważyli jednak, że zmiany w zakresie instytucji przebiegają wolniej aniżeli dynamika procesów rynkowych. Zrodziło to dwa wnioski. Po pierwsze, nieskrępowany rozwój rynku może prowadzić do zaburzeń w jego funkcjonowaniu. Objawiać się to może zawodnością rynku w zakresie konkurencji, dostępu do informacji czy też występowaniem efektów zewnętrznych (Brol, 2010, s. 70). Przedsiębiorstwa lub szerzej - gospodarka pozbawiona regulacji $\mathrm{w}$ sposób naturalny zmierza w kierunku monopolizacji, ograniczając efektywną alokację zasobów oraz szybkie dostosowywanie cen. Negatywny wpływ na funkcjonowanie rynku ma też utrudniony i kosztowny dostęp do pełnych informacji. Skutkiem jest funkcjonowanie jednostek w obszarze niedoskonałej informacji i występowanie różnic w poziomie wiedzy między uczestnikami wymiany rynkowej. Drugi ze sformułowanych wniosków odnosi się do roli państwa w gospodarce rynkowej. Zapewnienie wysokiej efektywności funkcjonowania rynku wymaga sprawnie działającego państwa, a także przestrzegania reguł nieformalnych, stworzonych oddolnie przez społeczeństwo (Dołęgowski, 2000, s. 23-24). Instytucjonaliści podzielali pogląd reprezentowany przez ekonomistów klasycznych, zadaniem których państwo było odpowiedzialne za kształtowanie ram prawnych, zapewnienie bezpieczeństwa obywatelom, ochronę praw własności i tworzenie warunków sprzyjających prowadzeniu działalności gospodarczej. Ponadto wielu z nich było przekonanych, że państwo powinno aktywnie angażować się $\mathrm{w}$ procesy gospodarcze, w sytuacji, kiedy mechanizm uczciwej konkurencji jest wypaczany (Zawiślińska, 2011, s. 607-616).

Przyjmując założenie, że oparta na etyce konkurencja korzystnie wpływa na efektywność funkcjonowania rynku i prowadzi do zwiększania dobrobytu w społeczeństwie, państwo powinno dążyć do osiągnięcia i utrzymania takiego właśnie stanu relacji między podmiotami w gospodarce. Problematyczna w tym względzie może okazać się postawa firm, zwłaszcza dużych korporacji, którym mechanizm konkurencji wolnorynkowej nie jest na rękę. Podmioty takie w swoich działaniach często kierują się zachowaniami typu rent-seeking. Dążą do osiągania zysków przez ograniczanie lub eliminację 
konkurencji. Zachowania typu rent-seeking burzą relację między wydajnością a dochodami i podważają wiarę społeczeństwa w istnienie uczciwej konkurencji rynkowej. Mając świadomość występowania przedstawionych mechanizmów, zaleceniem dla polityki gospodarczej państwa jest ograniczanie zachowań typu rent-seeking i aktywizowanie działań typu profit-seeking zmierzających do osiągania zysków przez obniżanie kosztów i zwiększanie wydajności. W grupie działań służących realizacji zalecenia wymienia się tworzenie państwowych instytucji kontrolnych oraz wprowadzanie ograniczeń budżetowych. Gromadzenie i dystrybucja informacji rynkowych ma na celu wspieranie uczciwej realizacji transakcji rynkowych, w których cena właściwie odzwierciedla relację dochodu do wydajności i ryzyka do dochodu. Ograniczanie wydatków budżetowych ma natomiast skłaniać przedsiębiorstwa do poszukiwania zyskownych działań na rynku, zamiast liczenia na pomoc ze strony państwa.

\section{NIEPEENA INFORMACJA W DECYZJACH RYNKOWYCH A POKUSA NADUŻYCIA}

Zjawisko niepełnej informacji zostało dostrzeżone i szerzej opisane w drugiej połowie XX w. Von Hayek wskazywał na rolę wiedzy i informacji w gospodarce. Inny laureat nagrody Nobla, Lucas zwrócił uwagę na niepewność, brak doskonałej informacji i wysokie koszty pozyskania danych rynkowych jako warunki funkcjonowania przedsiębiorstw. Podobnie autor teorii kosztów transakcyjnych, Coase, dowiódł, że pozyskanie wszystkich informacji dla realizacji transakcji jest niemożliwe i zbyt kosztowne (Kundera, 2011, s. 40). Pojęcie asymetrii informacji, leżącej u podstaw moralnego hazardu, wprowadził do ekonomii Mirrlees, natomiast najbardziej znane badania z tego zakresu prowadzili Akerlof, Stiglitz oraz Spence. Z kolei teorię agencji uwzględniającą zjawisko asymetrii informacji w kontekście rozbieżność celów i wysokości akceptowanego ryzyka przez podmioty uczestniczące w kontraktach zawartych w ramach korporacji opisali Jansen i Meckling (Waśniewski, 2011, s. 46).

Teoria agencji dotyczy zachowania dwóch podmiotów - pryncypała oraz jego agenta. Pryncypał zleca zadanie do wykonania agentowi i jest zależny od jego wiedzy i woli. W relacjach pryncypał-agent występuje asymetria informacji. Agent dysponuje większą aniżeli pryncypał ilością informacji na temat możliwych warunków transakcji czy stanu otoczenia gospodarczego. Skutkować to może podejmowaniem przez agenta działań charakteryzujących się wysokimi korzyściami własnymi, przy jednoczesnym narażaniu 
pryncypała na nadmierne ryzyko poniesienia strat. Dochodzi wówczas do moralnego hazardu.

Pokusa nadużycia, czyli zjawisko przeniesienia na pryncypała ryzyka ewentualnych strat wynikających z działań agenta, może nastąpić, gdy (Salanie, 2005, s. 119):

- użyteczność pryncypała i agenta uzależnione są od działań podejmowanych przez agenta,

- pryncypał nie jest w stanie w pełni kontrolować poczynań agenta, w związku z czym może obserwować jedynie rezultaty jego działalności,

- działania agenta nie są optymalne w sensie Pareto.

Zgodnie z założeniami teorii agencji, agent zostaje powołany do realizacji celów pryncypała. W działaniach może jednak uwzględniać również własne dążenia. Pryncypał, będąc świadomy konfliktu celów własnych i agenta, może zapobiegawczo kwestie te uregulować w umowie. Co prawda, teoretycznie wykonalne jest sporządzenie kontraktu zupełnego, uwzględniającego wszelkie możliwe warianty sytuacji rynkowej i zachowań agenta. W praktyce jednak kontrakt zupełny nie występuje. Pozostaje więc pewien obszar zależności pryncypała od woli agenta. Kontrola nad całokształtem poczynań agenta nie jest $\mathrm{z}$ kolei możliwa $\mathrm{z}$ racji rozmiarów kosztów, jakie należałoby w tym celu ponieść. Szczegółowa i częsta kontrola podważałaby także zaufanie do uczciwego agenta. Przy tak przedstawionych ograniczeniach nieuczciwy agent, kierując się względami egoistycznymi oraz wykazując zachowania oportunistyczne, może dążyć do realizacji własnych planów, które nie są optymalne z punktu widzenia efektywności pryncypała. Straty obciążające pryncypała na skutek nadmiernego ryzyka podejmowanego przez agenta mogą burzyć wzajemne zaufanie leżące u podstaw funkcjonowania gospodarki rynkowej.

\section{POKUSA NADUŻYCIA NA RYNKU USŁUG FINANSOWYCH}

Rynek finansowy jest miejscem, gdzie powszechnie występuje relacja pryncypał-agent. Agentem z reguły jest bankowiec, doradca finansowy lub makler papierów wartościowych. W roli pryncypała najczęściej występują klienci instytucji finansowych. Klienci, powierzając własne środki instytucjom finansowym, ufają, że zostaną one w możliwie najlepszy sposób ulokowane. Relację finansista-klient cechuje jednak duża asymetria informacji, co stwarza warunki do wystąpienia pokusy nadużycia. Klienci nieprofesjonalni wykazują się niedostateczną wiedzą z zakresu innowacji finansowych oraz brakiem umiejętności przewidywania konsekwencji podejmowanych decyzji inwestycyjnych. Postęp technologiczny wprawdzie obniżył koszty 
transakcyjne na rynku finansowym, ale nie wyeliminował kosztów zdobycia wiarygodnych informacji o ryzyku instrumentów finansowych. Czynniki te $\mathrm{w}$ połączeniu $\mathrm{z}$ chciwością, nadmiernymi oczekiwaniami i emocjonalnym podejściem do inwestycji czynią z klientów instytucji finansowych, szczególnie detalicznych, słabszą stronę, wystawioną na negatywne skutki moralnego hazardu przejawiającego się w działaniach ich doradców.

Przewaga finansistów w relacjach z klientami wynika z kilku powodów. Pierwszym źródłem, jak wspomniano, jest zasób posiadanej wiedzy na temat funkcjonowania rynku i cech dostępnych instrumentów finansowych. Drugim - wyważone, chłodne podejście w usłudze doradztwa z racji braku zaangażowania własnego kapitału. Kolejny czynnik to charakter kontaktu klienta z doradcą finansowym. Najczęściej doradztwo to jednorazowe działanie ograniczające się do rozwiązania konkretnej kwestii finansowej lub skorzystania z pewnej usługi finansowej. $\mathrm{W}$ takich warunkach klient nie może w pełni poznać motywacji doradcy. Nie tworzą się trwałe więzi między stronami biorącymi udział w procesie decyzyjnym.

Przedstawione uwarunkowania można często dostrzec, analizując zachowania uczestników rynku finansowego. Szczególna intensyfikacja zjawiska moralnego hazardu przejawiającego się w działaniach doradców miała miejsce w Polsce w latach 2005-2008 na rynku kredytów walutowych i funduszy inwestycyjnych. Warunkami sprzyjającymi moralnemu hazardowi były niedostateczne regulacje odnoszące się do konsekwencji prawnych z tytułu błędnego doradztwa oraz odpowiedzialności z tytułu braku pełnego opisu ryzyka instrumentów finansowych. Okolicznościami wzmagającymi zjawisko moralnego hazardu było umacnianie się złotego względem innych walut oraz pojawienie się hossy na rynku akcji, rynku surowcowym i nieruchomości.

Krajowe regulacje prawne odpowiedzialnością za podejmowane decyzje finansowe oraz ewentualne straty $\mathrm{z}$ nich wynikające niemalże całkowicie obciążają inwestorów. Nie trudno się więc dziwić, że potencjalni kredytobiorcy masowo zachęcani byli do zaciągania kredytów nominowanych w szczególności we franku szwajcarskim. Doradcy inkasowali prowizję od udzielonego kredytu, nie przejmując się potencjalnymi, a jak później okazało się, realnymi trudnościami w obsłudze kredytów spowodowanymi gwałtownym i trwałym osłabieniem złotego. Doradcy mieli świadomość, że kredyt hipoteczny zaciąga się zwykle raz w życiu, a sytuacji takiej towarzyszy z reguły brak oszczędności, które można byłoby ulokować w fundusze operujące na rynku papierów wartościowych. Mając to na uwadze, w perspektywie kilkuletniej doradztwo w zakresie kredytu było więc pierwszą i ostatnią operacją realizowaną w stosunku do danego klienta. Uczciwy doradca powinien 
wówczas przedstawić wszystkie potencjalne zagrożenia wynikające z ryzyka walutowego oraz obiektywnie ocenić możliwości finansowe klienta i jego najbliższej rodziny w okresie spłaty kredytu. Można jednak zakładać, że uzmysłowienie klientowi jego faktycznej zdolności kredytowej, w sytuacji gdy usilnie próbował on sfinansować pobudzone przez rynek aspiracje, skutkowałoby nie tyle zaniechaniem finansowania marzeń kredytem, ile skorzystaniem w usług mniej rzetelnego doradcy.

Podobne zjawisko - emocjonalne podejście klienta do usługi finansowej i moralny hazard przejawiający się w zachowaniach doradców - miało miejsce $\mathrm{w}$ zakresie lokowania środków w fundusze inwestycyjne. Profesjonalny doradca mógł z przekonaniem polecać działania za pomocą funduszy inwestycyjnych do pierwszych miesięcy 2006 r. Po gwałtownym załamaniu i miesięcznej korekcie na przełomie maja i czerwca 2006 r. coraz powszechniejsze było przekonanie o przewartościowaniu rynku akcji. Uczciwy doradca powinien wówczas zniechęcić klienta do inwestycji. Pozbawiłby się jednak w ten sposób okazji do osiągnięcia przychodu ze sprzedaży, a konkretnie opłaty dystrybucyjnej.

$\mathrm{Na}$ świecie asymetria informacji i zjawisko moralnego hazardu w relacjach zwierzchnik-agent $w$ ostatnich latach najwyraźniej zaznaczyły swoją obecność na rynku instrumentów opartych na amerykańskich kredytach hipotecznych oraz rynku kredytów hipotecznych w wielu krajach Europy. Moralny hazard cechował niemalże wszystkie podmioty zaangażowane w proces sekurytyzacji kredytów hipotecznych. Doradcy podsyłali bankom klientów bez zdolności kredytowej. Działali w przekonaniu, że ryzyko z tytułu udzielonych kredytów przechodziło na banki. Banki z kolei, dążąc do maksymalizowania sprzedaży i krótkoterminowych zysków, akceptowały obarczone wadą wnioski, łamiąc zasady zarządzania ryzykiem, gdyż zasadniczo ryzykowały środkami klientów. Całkiem realnie mogły też zakładać, że $\mathrm{w}$ przypadku poniesienia dotkliwych strat zostanie im udzielona pomoc ze strony państwa. Jednak najważniejsza była świadomość szybkiego pozbycia się udzielonego kredytu, który w ramach sekurytyzacji trafiał do spółek celowych. W dalszej kolejności banki inwestycyjne po przepakowaniu i wymieszaniu kredytów tworzyły CDO. Instrumenty te, podobnie jak MBS, trafiały do inwestorów na całym świecie, z których część zabezpieczała się przed ryzykiem kredytowym, nabywając przykładowo CDS. Wystawcy CDS, tacy jak AIG, faktycznie nie byli jednak w stanie zrealizować zobowiązań wynikających z tych instrumentów i podobnie jak banki musieli być ratowani setkami miliardów dolarów na koszt państwa, które w tej sytuacji okazywało się ostatecznym pryncypałem-płatnikiem. Ta ostatnia cecha w pewien sposób łączy amerykański systemem bankowym z europejskim. 
Mechanizm gwarantowania depozytów oraz akcje ratunkowe europejskich banków spowodowały, że koszty moralnego hazardu cechujące wszystkich uczestników systemu: deponentów, pracowników i zarządy banków oraz właścicieli tych instytucji, ostatecznie obciążyły państwo, a w konsekwencji ogół podatników. Wyjątek tutaj stanowiła Islandia, która zezwoliła na upadłość instytucji finansowych.

\section{PROFIT AND LOSS SHARING JAKO FILAR FINANSÓW ISLAMSKICH}

Finanse islamskie są częścią ekonomii islamu, która jako nauka ma swoje początki w latach 30. ubiegłego wieku. Pierwsze publikacje dotyczące kwestii gospodarowania uwzględniającego nakazy religii miały charakter bardziej polityczny i społeczny, a ich podstawowym celem była chęć ukazania odmienności kulturowej muzułmanów w brytyjskich Indiach. Ostatecznie działania te doprowadziły do powstania Pakistanu. Zainteresowanie przedstawicieli nauki krajów arabskich tą dziedziną wiedzy przypada na lata 50. XX w. (Nienhaus, 2010, s. 76-77).

Islam w krajach muzułmańskich to nie tylko religia. To system, to cywilizacja wywierająca wpływ na wszelkie aspekty życia społeczeństwa i jednostki (Krawczyk, 2013). Islam oraz wywodzące się z niego prawo - szariat - dotyczy także kwestii ekonomicznych (El-Gamal, 2006, s. 11-13). Człowiek w krajach muzułmańskich, podobnie jak na Zachodzie, gospodaruje w otoczeniu instytucji. W islamie religia jest instytucją, ale zarazem wywiera ona ogromny wpływ inne instytucje, takie jak prawo, akceptowane i zabronione zachowania ludzi, hierarchię wartości czy tradycyjne techniki finansów islamskich (Warde, 2010, s. 7).

Finanse islamskie uwzględniają ogólne zasady stosunków międzyludzkich zawarte w nauce islamu. Są nimi sprawiedliwość, równość szans oraz uwzględnianie w działaniach jednostki korzyści dla ogółu społeczeństwa. To, co odróżnia finanse islamskie od tradycyjnie pojmowanych finansów, to równy nacisk na zysk i kwestie moralne oraz etyczne postępowanie (Masood, 2011, s. 7-12; Greuning, Iqbal, 2008, s. 5). Za cechy, które najmocniej kojarzone są z finansami islamskimi, można uznać brak możliwości pobierania lub płacenia odsetek, a ściślej kwestię ujmując - jakiejkolwiek nadwyżki, zakaz finansowania lub czerpania pożytków z działalności niedozwolonych, jak hazard czy handel bronią, oraz unikanie niepewności w kontraktach (Akkizidis, Khandelwal, 2008, s. 2-7).

Finanse islamskie mocno akcentują jeszcze jedną zasadę - uczestnictwo w zyskach i stratach przedsięwzięcia. Koncepcja PLS wiąże się z przekonaniem, że jedynym akceptowanym sposobem osiągania korzyści z transakcji 
jest uwzględnienie ryzyka w działalności, otwarcie ekspozycji wiążącej się z możliwością poniesienia straty (Ayub, 2007, s. 81). Muzułmanie uważają za niewłaściwe określenie making money. Ich zdaniem należy stosować earning money (Abdul-Rahman, 2010, s. 7). Pieniądze same w sobie nie są towarem i nie mogą przynosić korzyści. Handel jest najlepszym sposobem zarabiania pieniędzy. Handel wyraża się w zakupie aktywów, których cena rynkowa może zmienić się w przyszłości. Tylko podjęcie ryzyka daje podstawy do osiągania moralnego zysku (Askari i in., 2012).

Tradycyjne techniki finansów islamskich, takie jak Mudaraba i Musharaka, skonstruowane są w oparciu o zasadę PLS. Techniki te są formą kapitałowego partnerstwa, gdzie jedna strona dostarcza finansowanie, druga zaś, wykorzystując wiedzę i umiejętności, angażuje środki w przedsięwzięcie gospodarcze. Różny w tych kontraktach jest wpływ finansującego na realizowany projekt, inne są też dla obu stron finansowe konsekwencje niepowodzenia projektu. Zasadniczym warunkiem stosowania tych technik jest wzajemne zaufanie między stronami kontraktu (Iqbal, Mirakhor, 2007, s. 304).

Finansowanie w oparciu o PLS stawiane jest często w opozycji do finansowania długiem. Wskazuje się na potencjalnie wyższą efektywność tej formy finansowania. Podkreśla się, że przy finansowaniu długiem uwagę przywiązuje się głównie do kwestii zdolności kredytowej i zabezpieczenia. Odmiennie sytuacja przedstawia się przy Mudarabie i Musharace, gdzie akceptacja projektów dokonywana jest po analizie ich potencjalnej efektywności. Akceptowane są tylko przedsięwzięcia dające szansę wypracowania wysokiej stopy zwrotu (Obaidullah, 2005, s. 57-60).

Przytoczone zalety nie rekompensują w pełni wad formy finansowania opartej na partnerstwie. Dlatego w rzeczywistości banki islamskie tylko $\mathrm{w}$ niewielkim stopniu korzystają $\mathrm{z}$ produktów zawierających warunek uczestnictwa w zyskach i stratach, częściej korzystając z finansowania długiem w oparciu o zasadę Mudaraby. Jest to więc sytuacja podobna do obserwowanej w konwencjonalnych finansach, gdzie venture capital ustępuje finansowaniu kredytem. Banki islamskie wykorzystują formułę PLS do pozyskiwania depozytów. Stosują tę technikę, gdyż występują wówczas w roli agenta deponentów. Zupełnie odmiennie wygląda sytuacja w zakresie aktywów. Banki nie są skłonne wykorzystywać instrumentów opartych na partnerstwie, gdyż świadome są dużego ryzyka moralnego hazardu oraz negatywnej selekcji. Banki, występując w roli finansującego, czyli pryncypała, obawiają się, że przekazane środki zostaną wykorzystane w sposób niezgodny z umową, a raportowane zyski przedsięwzięcia będą zaniżane. Ponadto konieczność monitorowania realizacji projektów znacznie zwiększa koszty usług finansowych $\mathrm{z}$ wbudowaną konstrukcją PLS, zmniejszając ich atrak- 
cyjność dla banków (Khan, 2010, s. 812; Iqbal, Molyneux, 2005, s. 143-149).

Stosowanie zasady PLS wymaga wskazania poziomu uczestnictwa stron w wypracowanych zyskach lub poniesionych stratach. Kwestia pokrycia strat uregulowana jest przez prawo i tradycję islamu. Poziom partycypacji w zyskach uzależniony jest natomiast od wartości i charakteru przedsięwzięcia i może być dowolnie kształtowany przez strony kontraktu. Jak wykazały badania, banki oferujące produkty zgodne $\mathrm{z}$ zasadami szariatu ustalają poziom dystrybucji dochodów tym niższy, im większy jest stopień religijności obsługiwanych klientów (Farook, Hassan, 2012, s. 333-347). Kolejnym wymogiem jest, aby udział w zyskach był określony jako procent dochodu, nie zaś jako pewna kwota dochodu. Podanie konkretnej kwoty wynagrodzenia w kontrakcie eliminowałoby ryzyko dla jednej strony umowy i czyniłoby ową kwotę nadwyżką nieakceptowaną przez islam.

\section{WDROŻENIE KONCEPCJI PLS W WYBRANYCH USŁUGACH FINANSOWYCH}

Wykorzystanie formuły PLS jako formy wynagrodzenia i sposobu motywowania agenta $w$ transakcjach na rynku finansowym jest możliwe, ale nie w każdej sytuacji oraz nie przez bezpośrednie przeniesienie wzorców z finansów islamskich na krajowy grunt.

Transakcje, w których uczestniczą tylko podmioty profesjonalne, w myśl ustawy o obrocie instrumentami finansowymi, mogą być pozbawione mechanizmu partycypacji. Podmioty profesjonalne powinny mieć wiedzę o konstrukcji instrumentów finansowych i doświadczenie pozwalające oszacować ryzyko decyzji inwestycyjnych. Ocena działań agenta pod kątem moralnego hazardu nie powinna stanowić dla nich trudności.

Inaczej sytuacja przedstawia się, gdy pod uwagę weźmie się transakcje realizowane przez klientów nieprofesjonalnych, detalicznych. Jak wspomniano wcześniej, doradcy finansowi mają nad nimi przewagę i mogą ją wykorzystać, stosując moralny hazard. Przy takich usługach wykorzystanie formuły udziału w zyskach i stratach, pozbawionej kontekstu religijnego i wynikających z tego szczegółowych zasad, wydaje się uzasadnione. W dalszej części pracy rozważania skupią się na usługach doradztwa na rynku funduszy inwestycyjnych i kredytów walutowych.

Doradca świadczący usługi na rynku funduszy inwestycyjnych swoje przekonanie o rozwoju sytuacji na rynku mógłby potwierdzić, godząc się na zawarcie umowy cywilnej z klientem zawierającej formułę PLS. Umowa powinna określać horyzont czasowy obowiązywania, wielkość zainwesto- 
wanych przez klienta środków oraz sposób wyznaczania stopy zwrotu. Powinna także zawierać zobowiązanie stron do wypłaty części zysku lub pokrycia części straty. Mechanizm partycypacji może być uruchamiany przy jakimkolwiek zysku/stracie lub po przekroczeniu wielkości progowej, przykładowo $10 \%$ wartości początkowej portfela. Udział w zyskach i stratach powinien być określony na takim poziomie, aby zredukować w działaniach doradcy zjawisko moralnego hazardu. Obawa przed utratą własnych pieniędzy powinna powstrzymać doradcę przed udzieleniem nieprzemyślanej porady - takiej, w której trafność sam się nie wierzy. Aby mechanizm redukcji moralnego hazardu był skuteczny, wysokość ewentualnych strat powinna stanowić znaczącą część kwoty opłaty dystrybucyjnej, jaką otrzymuje doradca od towarzystwa funduszy inwestycyjnych. Agent powinien wykazać się także określonym poziomem środków we właściwy sposób zabezpieczonych celem pokrycia potencjalnych przyszłych zobowiązań wobec pryncypała.

W przypadku kredytów hipotecznych dla klientów detalicznych stosowanie formuły PLS byłoby wskazane przy kredytach wyrażonych w walutach obcych. Kredyty złotowe charakteryzują się mniejszą zmiennością. Brak jest w nich ryzyka walutowego, natomiast stopa oprocentowania uzależniona zwykle pośrednio od poziomu inflacji nie podlega gwałtownym zmianom. Zjawisko molarnego hazardu nie ma więc podłoża w zmienności przyszłych uwarunkowań gospodarczych, a wynikać zasadniczo może z nieprawidłowego oszacowania zdolności kredytowej klienta. Jednak ten obszar ryzyka związany finansowaniem długiem powinien przede wszystkim obciążać klienta. Od kredytobiorcy wymaga się bowiem przewidywania, realizmu i racjonalności w postępowaniu.

Warunki umowy między klientem a agentem przy kredycie walutowym mogą być w znacznym stopniu tożsame $\mathrm{z}$ przedstawionymi wcześniej propozycjami dla inwestycji $\mathrm{w}$ fundusze. $\mathrm{W}$ inny sposób należałoby jednak w takich kontraktach określić okoliczności uruchamiania mechanizmu uczestnictwa w zyskach lub pokrycia strat. Głównym czynnikiem sprawczym zjawiska moralnego hazardu jest tutaj ryzyko walutowe, związane ze znacznym i trwałym osłabieniem złotego. Formuła PLS powinna więc odnosić się do tej niekorzystnej możliwości. Należy przyjąć kurs walutowy, przykładowo różniący się +/- 20-30\% od kursu z dnia zaciągnięcia kredytu. Osiągniecie takiego poziomu przez kurs w przypadku osłabienia waluty krajowej, praktycznie niweluje przewagę kredytu walutowego w stosunku do złotowego. W umowie należy wskazać źródło odczytu wartości kursu. Aby warunek PLS został aktywowany, niekorzystna dla kredytobiorcy zmiana powinna utrzymywać się przez dłuższy okres, przykładowo rok. Wówczas 
agent zobowiązany byłby do przekazania pryncypałowi określonej kwoty zbliżonej wartością do prowizji z tytułu pośrednictwa, jaką wcześniej otrzymał od banku. W sytuacji znacznego i trwałego umocnienia złotego, płatność o takiej samej kwocie zasiliłaby rachunek agenta.

Ostatnią kwestią, którą należałoby uwzględnić przy stosowaniu umów opartych o koncepcję PLS, jest zakres odpowiedzialności agenta. W analizie konieczne jest dokonanie rozróżnienia na doradcę działającego na własny rachunek oraz doradcę świadczącego usługi w ramach instytucji finansowej. Doradca prowadzący działalność gospodarczą, dopuszczając się moralnego hazardu, czyni to $\mathrm{z}$ własnej woli i ze świadomością ewentualnego niezadowolenia klientów $\mathrm{z}$ tytułu poniesionych $\mathrm{w}$ przyszłości strat. Zawieranie umów z takimi agentami wydaje się warunkiem niezbędnym, by ograniczyć zjawisko moralnego hazardu. Bardziej skomplikowana sytuacja występuje w przypadku doradców bankowych. $\mathrm{Z}$ reguły osoby takie, działając w lokalnych środowiskach, starają się zbudować dobre relacje $\mathrm{z}$ obsługiwanymi klientami. Jednocześnie muszą realizować plany sprzedażowe narzucane przez centrale. Stopień ich realizacji wpływa z kolei na wysokość wynagrodzenia. W tej sytuacji agentem klienta skłonnym do moralnego hazardu jest nie tylko doradca, ale cała instytucja finansowa, którą on reprezentuje. Umowa określająca warunki partycypacji powinna więc ujmować trzy strony: klienta, doradcę oraz instytucję finansową.

\section{PODSUMOWANIE}

Moralny hazard można rozpatrywać w kategoriach społecznych i etycznych. Moralny hazard to także zjawisko ekonomiczne. Wpływa ono niekorzystnie na efektywność funkcjonowania rynku i z tego względu powinno być ograniczane. Ukształtowane w toku rozwoju społecznego wartości, takie jak prawo i zwyczaje, pozwalają redukować niepewność w działalności ekonomicznej i przyczyniają się do obniżki kosztów transakcyjnych.

Świat islamu wypracował własne instytucje oparte na szariacie. Wiele zasad, regulacji i zachowań z racji swej odmienności nie ma zastosowań w krajach kultury Zachodu. Jednak formuła dzielenia zysków i strat, instytucja znana finansom islamskim, mogłaby być z powodzeniem szeroko stosowana na rynku konwencjonalnych usług finansowych. Jej wdrożenie przyniosłoby pozytywne efekty w postaci redukcji zjawiska moralnego hazardu. Przejawiałoby się to bardziej wyważonymi i przemyślanymi zaleceniami formułowanymi przez doradców. Agenci nie wykazywaliby już nadmiernej skłonności do podejmowania ryzyka na koszt klienta. Obawa o uczestnictwo finansowe w stratach mogłaby skutecznie hamować stosowanie zbyt ryzy- 
kownych strategii i instrumentów. Jednocześnie, profesjonalny doradca, potrafiący prognozować przyszłe zachowania rynku, zgadzając się na podpisanie z klientem umowy z warunkiem PLS, mógłby potwierdzić przekonanie o swoich umiejętnościach oraz liczyć na dodatkowy zysk z usługi. Czynnik, który ograniczał praktyczne stosowanie tej koncepcji w islamskich produktach finansowych, a mianowicie konieczność monitorowania finansowanego projektu i zachowań agenta, w tym przypadku klienta banku islamskiego, ma tutaj niewielkie znaczenie. Wynika to $\mathrm{z}$ faktu, że usługa doradztwa na rynku finansowym i związana $\mathrm{z}$ tym zależność pryncypała od postawy agenta jest najczęściej zdarzeniem jednorazowym o ograniczonych kosztach analiz.

Formuła udziału w zyskach i stratach jest jednym, ale nie jedynym sposobem ograniczania moralnego hazardu. Klient, pryncypał, korzystając $\mathrm{z}$ usług na rynku finansowym, powinien:

- rozważyć zasadność podjęcia decyzji inwestycyjnej,

- zdobyć wiedzę na temat danego rynku, instrumentu i doradcy,

- zgromadzić dane pozwalające przewidzieć kierunek rozwoju rynku,

- określić, w miarę swoich możliwości, motywację działań agenta.

Państwo z kolei, jako podmiot chroniący w sposób szczególny interesy najsłabszych, powinno:

- gromadzić i dystrybuować dane na temat funkcjonowania rynku finansowego celem zmniejszenia asymetrii informacji między uczestnikami rynku,

- udostępniać raporty wskazujące na praktyki naruszania interesów klientów instytucji finansowych,

- wprowadzać regulacje prawne ograniczające możliwość wystąpienia moralnego hazardu.

Rzetelność analizy wymaga stwierdzenia, że pewne działania w zakresie regulacji prawnych zostały już podjęte. Wprowadzono wymóg informowania klienta o ryzyku inwestycyjnym na rynku finansowym oraz określania jego profilu z punktu widzenia akceptacji poziomu ryzyka. Podniesiono także wymagania przy badaniu zdolności kredytowej osób ubiegających się o kredyty hipoteczne, w szczególności walutowe.

\section{LITERATURA}

Abdul-Rahman Y. (2010), The Art of Islamic Banking and Finance. Tools and Techniques for Community-Based Banking, John Wiley \& Sons Inc, Hoboken.

Akkizidis I., Khandelwal S. K. (2008), Financial Risk Management for Islamic Banking and Finance, Palgrave Macmillan, New York.

Askari H., Iqbal Z., Krichne N., Mirakhor A. (2012), Risk Sharing in Finance. The Islamic Finance Alternative, John Wiley \& Sons Ltd, Singapore. 
Ayub M. (2007), Understanding Islamic Finance, John Wiley \& Sons Ltd, Chichester.

Bartkowiak R. (2008), Historia myśli ekonomicznej, PWE, Warszawa.

Brol M. (2010), Zarys ekonomii sektora publicznego, Wydawnictwo Uniwersytetu Ekonomicznego we Wrocławiu, Wrocław.

Dołęgowski T. (2000), Konkurencyjność a procesy integracyjne w Europie, SGH, Warszawa.

El-Gamal M. A. (2006), Islamic Finance. Law, Economics, and Practice, Cambridge University Press, New York.

Farook S., Hassan M. K., Clinch G. (2012), Profit distribution management by Islamic banks: An empirical investigation, „The Quarterly Review of Economics and Finance”, 52, DOI: http://dx.doi.org/10.1016\%2Fj.qref.2012.04.007.

Greuning H., Iqbal Z. (2008), Risk Analysis for Islamic Banks, The World Bank, Washington, DOI: http://dx.doi.org/10.1596/978-0-8213-7141-1.

Iqbal M., Molyneux P. (2005), Thirty Years of Islamic Banking. History, Performance and Prospectus, Palgrave Macmillan, London.

Iqbal Z., Mirakhor A. (2007), An Introduction to Islamic Finance. Theory and Practice, John Wiley \& Sons, Singapore.

Khan F. (2010), How „Islamic” is Islamic Banking?, „Journal of Economic Behavior \& Organization", 76, DOI: http://dx.doi.org/10.1016/j.jebo.2010.09.015.

Krawczyk R. (2013), Islam jako system społeczno-gospodarczy, Oficyna Wydawnicza Uczelni Łazarskiego, Warszawa.

Kundera E. (2011), Państwo w gospodarce w ujęciu doktryny liberalnej, [w:] Kalina-Prasznic U. (red.), Państwo i rynek. Obszary zawodności, Gaskor, Wrocław.

Masood O. (2011), Islamic Banking and Finance. Definitive Texts and Cases, Palgrave Macmillan, New York.

Nienhaus V. (2010), Fundamentals of an Islamic Economic System Compared to the Social Market Economy. A Systematic Overview, KAS International Reports, 11, http://www.kas.de/wf/en/33.21079/ (15.11.2013).

Obaidullah M. (2005), Islamic Financial Services, King Abdulaziz University, Jeddah.

Rudolf S. (2012), Nowa ekonomia instytucjonalna lekarstwem na kryzys, [w:] Rudolf S. (red.), Nowa ekonomia instytucjonalna wobec kryzysu gospodarczego, Wydawnictwo Wyższej Szkoły Ekonomii i Prawa im. prof. E. Lipińskiego w Kielcach, Kielce.

Salanie B. (2005), The Economics of Contracts, The MIT Press, Cambridge.

Stankiewicz W. (2007), Historia myśli ekonomicznej, PWE, Warszawa.

Warde I. (2010), Islamic Finance in the Global Economy, Edinburgh University Press, Edinburgh

Waśniewski K. (2011), Decyzje inwestycyjne wspótczesnej korporacji - dylematy racjonalności, Krakowska Akademia im. A. F. Modrzewskiego, Kraków.

Williamson O. E. (1998), Ekonomiczne instytucje kapitalizmu. Firmy, rynki, relacje kontraktowe, PWN, Warszawa.

Włudyka T., Smaga M. (2012), Instytucje gospodarki rynkowej, Lex a Wolters Kluwer business, Warszawa.

Zawiślińska I. (2011), Państwo i gospodarka, [w:] Oniszczuk J. (red.), Wspótczesne państwo w teorii i praktyce, Oficyna Wydawnicza SGH w Warszawie, Warszawa. 


\title{
IMPLEMENTING THE FUNDAMENTAL PRINCIPLE OF ISLAMIC FINANCE PLS IN ORDER TO REDUCE MORAL HAZARD ON THE FINANCIAL SERVICES MARKET
}

\begin{abstract}
A b s t r a c t. Moral hazard is a situation where agent takes a risky actions, knowing that potential costs will be born by principal. In finance, moral hazard arises when advisers take risky decisions come to believe that they will not have to carry the full burden of potential loses. Implementing the fundamental principle of Islamic finance PLS could reduce moral hazard on financial services market.

K e y w or d s: moral hazard, Islamic finance, financial advisory, profit and loss sharing.
\end{abstract}


